\title{
Revitalizing Japan's Mountainous Areas through Green Tourism: A Human Geographical Perspective
}

\author{
Abhik Chakraborty (Corresponding Author) \\ Human Geography, Izu Peninsula Geopark \\ 2-1-1 Ohara, Ito, Shizuoka 414-8555, Japan \\ Tel: 81-557-32-1784Ｅ-mail: abhik78@ @otmail.co.jp

\begin{abstract}
Munehiko Asamizu
Faculty of Economics, Yamaguchi University

1677-1, Yoshida, Yamaguchi 753-8514, Japan

E-mail: masamizu@ yamaguchi-u.ac.jp
\end{abstract}

Received: March 22, 2013 Accepted: April 11, 2014 Published: May 12, 2014

doi:10.5296/iss.v2i1.5340 URL: http://dx.doi.org/10.5296/iss. v2i1.5340

\begin{abstract}
This paper explores Nature-Based Tourism, particularly 'green tourism' and rural to urism in mountainous areas of Japan. Japan witnessed an exceptional growth of 'green tourism' activities since the 1990s, which took place in the general backdrop of hyper-aging and demographic decline in the rural areas. Since the 1990s, nature based tourism activities have raised the hope that increased awareness about nature and traditional lifestyle will help offset economic decline, promote rural-urban interaction and eventually bring new residents to depopulated hinterlands. This paper is based on field research in two of the most extremely depopulated areas in Japan, located in Yamaguchi and Shimane Prefectures. The research identified several encouraging new trends, such as the emergence of beautiful river basin landscapes as tourism destinations, a growing interest in experiencing traditional rural lifestyle, and involvement of citizen volunteers, schoolchildren and non-profit organizations (NPOs) in tourism promotion and landscape management. However, rural destinations are often packaged as a form of nostalgia for urban visitors. The research also found that the nature conservation agenda has lagged behind the economic revitalization agenda, general awareness level about rural landscapes remains low, and it is difficult to sustain volunteer interest over time. Thus while there are several limitations, 'green' tourism in depopulated
\end{abstract}




\section{Macrothink

Issues in Social Science

rural mountainous regions of Japan potentially offers a new pathway to sustainable tourism.

Keywords: 'Green tourism', Mountainous regions, Demographic transition, Nature conservation, Landscape, Japan 


\section{Introduction: Nature-Based Tourism and "Green Tourism" in Japan}

The term "Green tourism" became popular in Japan from the 1990s (Inoue et al., 1996; Miyazaki, 2011). The term is generally used for a broad range of tourist activities centering on agricultural villages, the traditional 'satoyama' landscape (Note 1) and the concept of 'rural-urban interaction' (Aoki, 2010; Miyashita, 2006; Tanaka, 2002). The central importance of 'rural-urban interaction' is evidenced by the implementation of the 'Agricultural village-stay leisure law' (Note 2) in 1995 (Chûsankan Chiiki wo Kangaeru Kai, n. d.) by the Ministry of Agriculture, Forestry and Fis heries (MAFF). Eventually, the central government adopted green tourism as an important part of the 'Tourism Nation Promotion Basic Plan' in 2007 (MAFF, n. d.). The MAFF definition of green tourism is centered on the 'villages' or 'rural areas' of Japan, which are affected by a long and steady economic decline starting from the latter half of the twentieth century (Ono, 2008; Matanle \& Rausch, 2011). It is worth noting the MAFF definition for green tourism here: "[Green tourism is] a form of leisure activity based on visitor stay in agricultural villages and enjoying the interaction between nature, culture and people" (MAFF, n. d.). This definition was standardized by the so called Green Tourism Law (Agricultural village-stay leisure law), passed in 1994 and implemented in 1995. This pattern of tourism is promoted as 'developing a new kind of life-cycle' based on mutual appreciation between urban and rural areas, and development of a network of people, products and information (MAFF, n. d.). In this sense, it is nature-based tourism (NBT) with a particular focus on villages engaged in agriculture (mainly rice farming), community forestry and fishing, and a goal of 'revitalizing' these rural landscapes. Jones (2013) has suggested that NBT itself has gone through a 'life cycle' in modern Japan, its different phases consistent with major sociopolitical transitions, such as consolidation of the state mandate on land and natural resources beginning from the Meiji (1868-1912) period, intensification of growth and natural degradation in the postwar era, stagnation and decline during the bursting of the growth bubble and rejuvenation in the post-bubble growth period. Jones also documents that mainstream NBT has 'evolved' in Japan, from an exclusive focus on the national parks and managed tours during the growth era to a more diffuse and 'low-impact' form of tourism in satoyama-satoumi areas, with a focus on rural Japan in general during the 'post growth' phase. Ecotourism, and other low-impact, rural or wilderness based activities are major themes in recent NBT activities in Japan. An important trend is 'place-specific' tourism which emerged during this period. Known in Japanese as 'Chakuchi-gata', this concept underlines the importance of 'actually experiencing' rural life, rather than simply consuming the rural landscape (Takata, 2013). The overall trend therefore, is consistent with other economically developed countries, such as those in Europe-where rural tourism is coupled with the 'sustainable livelihoods approach' (Campbell and Lopez Ortiz, 2011) that is distinguished by a focus on farm-stay and experiencing the rural way of life. This approach is not merely about visiting places but also linked to education about sustainable livelihoods (Francis et al., 2012; Sidali et al., 2011). Green tourism in Japan is also increasingly being considered as a way of educating urban generations about cultural association with nature, knowledge and techniques associated with food production, and about 'identity' of a native place, generated through visiting rural areas (Ackermann et al. 2008). 


\section{Rural hinterlands in Japan: Decline and Demography}

The demographic transition in Japan is a well-researched phenomenon. The demographic transition was precipitated by the fertility decline during the postwar period (Retherford et al., 1996; Fauruqee \& Muhleisen, 2001). In fact, the entire postwar phase of Japanese history is seen as one of long term fertility decline, and consequent demographic shrinkage (Faruqee \& Muhleisen, 2001) - with the most recent and significant spike in demographic decline beginning in the 1970s. While the average childbirth per woman was 4.54 in 1947, it fell to 1.50 in 1973 (Ogawa \& Retherford, 1993). Aging and a rise in the life expectancy simultaneously pushed the remaining population into a 'grey' zone, with the percentile of the older generation rising steadily (Matanle \& Rausch, 2011). The 'aged' population (meaning those over 65 years of age) was only $5 \%$ in 1950, but steadily swelled to $12 \%$ in 1990, and is projected to rise to $25 \%$ in 2020 (Ogawa, 1989). This is consistent with the pattern observed by Van de Kaa (1987) that populations in advanced industrial countries would eventually enter a second demographic transition, i.e. a phase of continual shrinkage that cannot be offset by new in-migration or structural alteration of the population. In the case of Japan, these effects are most acutely felt in the rural areas, or the 'hinterland' regions that have not witnessed development of large industrial infrastructure like those in the Pacific seaboard (in the vicinity of Tokyo) or the Kansai region (near Osaka-Kyoto-Kobe) (Matanle \& Rausch, 2011). Ono (2008) documents how small rural communities in remote regions are facing imminent collapse, as over $50 \%$ of the population in these communities is aged over 65 . He terms these communities as 'extremely depopulated villages' (genkai shûraku). According to the Ministry of Land, Infrastructure, Transport and Tourism (MLIT), over 7800 extremely depopulated villages currently exist in Japan and over 400 of these might disappear entirely within a decade - which means there is ongoing significant depletion and disappearance of entire village communities even as this article is being written.

Our research suggests that the effects of sustained demographic decline and low births are felt even more disproportionately in the remote rural villages of Japan, owing to the nature of their economy. Japanese villages have predominantly been rice farming communities, and the policies by the postwar Japanese state encouraged rice farming even more, by providing subsidies (Ohnuki-Tierney, 1994; Kawagoe, 1999). Rice farming is a laborious process that needs extensive land clearing, maintenance of rice paddies (guarding the crop from forces of weather and invasion by other plants) and caring of the rice plant by irrigating and monitoring the crop. Once demographic decline sets in, the rice farming communities feel the process more acutely, as there is lesser and lesser able hands to maintain the rice crop. This pattern is is even more pronounced where the farming villages are located in mountainous regions, away from the fertile deltas or flat alluvial plains where agriculture is largely mechanized and irrigation provisions are easily available. Thus, mountainous areas of Japan represent the most acute case of the postwar demographic transition as far as decline of local economies and communities is concerned.

The role of tourism to revitalize such communities is an emerging research theme. While it is generally hoped that rural travel and urban-rural exchange can provide a much needed window for the struggling communities to renew a sense of identity and also facilitate 


\section{Macrothink Institute ${ }^{T M}$}

repopulating the countryside, actual effects have either been extremely limited or insignificant to stem demographic decline (Matanle \& Rausch, 2011). Nevertheless, we contend that studying these regions as tourist destinations offer significant prospects. While many communities will inevitably disappear as Japan shifts into a hyper-aged society, they remain important locations due to the strong connection of the rural population with nature, a history of low-impact lifestyle and traditional knowledge of environmental management. Together, these aspects are vital for developing any ecotourism or green tourism vision, and must be thoroughly evaluated before the villages disappear altogether.

\section{Research Method}

This research is mainly based on fieldwork carried out in the Yamaguchi and Shimane prefectures, located in the southern and southwestern tips of the main is land of Japan, Honshu. The researchers visited a large number of mountain villages spanning a period of three years. In Shimane, the study sites are located along the 81 kilometer long Takatsu River, which flows through some of the most extremely depopulated communities in the country. In Yamaguchi the main study site is located in the Nishiki River Basin, known as one of the most visually beautiful areas in the prefecture.

In depth interviews, mapping of cultural histories and participant observation were used for the field research. The research framework was qualitative, which allowed the researchers to compare the significance of the findings across multiple levels (Patton, 2001, Creswell, 2002), and explore dichotomies in narratives. The field-based design is considered especially appropriate for exploring the relationships between communities and nature from environmental sociological and human geographical perspective (Vaccaro et al. 2010) and the participatory nature of the fieldwork is deemed vital for analysis of tourism activities based in particular cultural settings (Richards \& Munsters, 2010). The findings were compared with data from content analysis regarding the general backdrop and wider significance.

\section{Case Studies: 'Mountainous Regions' in Yamaguchi and Shimane Prefectures}

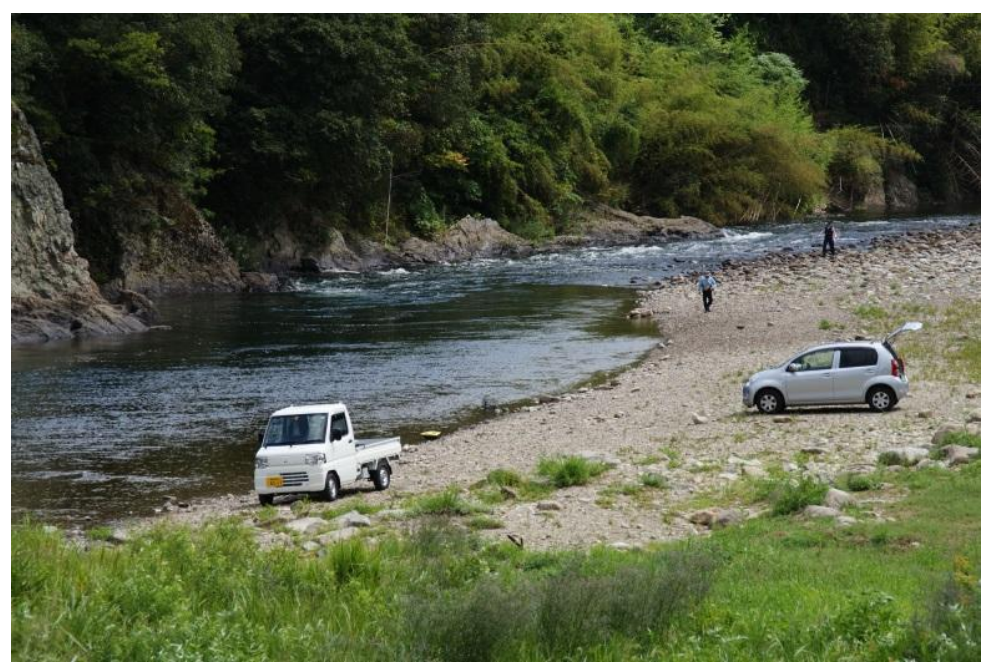

Figure 1. Fishing enthusiasts enjoying a summer day near a clear stream in Shimane: A typical river landscape in the mountainous regions of West Japan 
In this paper, we look at two river basins in Yamaguchi and Shimane Prefectures. In the Yamaguchi Prefecture, the focus in on the Nishiki River watershed, and in Shimane, the Takatsu River watershed (photo in Figure 1 above) is explored. Incidentally, geological studies spread across these two watersheds have revealed that the two rivers used to flow in an interconnected network of waterways, before artificial channel alteration in historic times (Yamauchi and Shiraishi, 2010). The two watershed areas share many similarities in landscapes, the most prominent one is the prevalence of mountains, and narrow valleys where human habitations are concentrated. Both basins, due to their topographic features, have precluded large scale industrial or traffic infrastructure development. Both areas are thus typical 'mountainous regions' (chûsankan chiiki): a term specifically used to denote mountain villages and towns in Japan which are facing threats like aging, depopulation, and lack of urban economic development (Seki and Matsunaga, 2010). The term has recently attracted scholarly and policy attention, due to the fact that such 'mountainous regions' are the most adversely affected by the demographic transition, while they retain naturally rich, beautiful landscapes ideally suited for rural tourism. The MAFF observes that $73 \%$ of the land area in Japan can be classified as 'mountainous regions', which together cover $40 \%$ of all cultivated land, nearly $44 \%$ of the total population, and nearly $35 \%$ of the total agricultural produce of the country (MAFF, n.d.). In this sense, areas like the Nishiki and Takatsu River watersheds are fairly typical of the general rural land scape of Japan. Seki (2007) has pointed out that the Shimane example is a representative case for rural regions in Japan, and although these are as are generally seen as 'inhibited by natural constraints (jôken-fu-ri-chiiki) (Miyazaki, 2000), they are also deemed extremely important for 'sustainable regional planning' in a post growth Japan, and as model regions of relatively low-impact, close-to-nature lifestyle (Ibid).

\subsection{Yamaguchi Prefecture: Green Tourism at a Glance}

Yamaguchi Prefecture is located at the southern tip of the largest and the central island of the Japanese archipelago, Honshu. The prefecture has a total area of 6111 sq.km, and a total population of 1,421,370 (Yamaguchi Prefecture, 2013). The prefecture is seriously affected by aging and depopulation in the rural areas. In 2012, $29.2 \%$ of the population was aged 65 and above. What is alarming is that the $0-14$ year cohort was smaller in size (12.6\%) than the hyper-aged cohort (aged 75 and above) which stood at 15.6\% (Yamaguchi Prefecture, 2013). Thus the long term prediction, in demographic terms, is that of an increasingly hyper aged society, with advancing depopulation the resultant effect. 4200 sq.km. (i.e. nearly $70 \%$ ) of the land area is considered as 'mountainous' and as of 2010,367,000 people inhabited this area. This shows that the mountainous regions in the prefecture are very sparsely populated.

The urban infrastructure and comparatively dense human habitations are concentrated in the southern part of the prefecture. Yamaguchi City (the prefecture capital), Shimonoseki City, Ube City and Shûnan City are some major urban areas. The northern part of the prefecture is mainly rural. During the 'Great Merger of 2006 (heisei dai-gappei'), many rural units were amalgamated into urban areas - this is seen as an important milestone as far as rural-urban tourist interchange in the prefecture is concerned (Asamizu, 2012).

As noted earlier, green tourism centering on urban-rural interactions became a policy focus at 


\section{Macrothink Institute ${ }^{T M}$}

the national level with the passage of the Green Tourism Law in 1994. In 1997, Yamaguchi Prefecture issued a green tourism manual - this document focused on the rural lifestyle and sought to develop it as a tourism package. Notable examples of this 'rural life' were Towa, Aga, Nishiki, Kumage and Ato Towns, all of which were amalgamated into larger municipal bodies in 2006 (Note 3). In particular, Towa, or the Suo-Ôshima Island became famous as a 'successful model' of developing rural tourism.

Early efforts to increase urban-rural exchange through tourism in Yamaguchi began with a focus on high school students, who go on to 'educational trips' or excursions every year in Japan. Initial figures were modest: between 1989 and 1996 only 224 high school students could be attracted to a program called Kôkôsei-nôka Hômusutei Suishin Jigyô (Homestay Promotion for High School Students). Green Tourism and Slow Tourism Promotion Plans were formulated in 2004 and 2011 respectively. In 2011, the Slow Tourism Promotion Plan had a funding of 32 million Yen (Asamizu, 2012). Eventually, two types of tourism promotion involving schoolchildren developed: the first one primarily draws elementary schoolchildren from the relatively urbanized parts of Yamaguchi and surrounding prefectures like Hiroshima and Shimane, and the second type mainly draws high school students from large urban conglomerations like Tokyo and Osaka. University students have emerged as another focus group - with Yamaguchi University as the leading stakeholder. Students of Yamaguchi University provide farming help in the rural areas through various programs run by the Faculty of Agriculture, the Faculty of Education and the Faculty of Economics.

Yamashiro (Yamaguchi): A Case of Promoting Tourism through Educational Excursions:

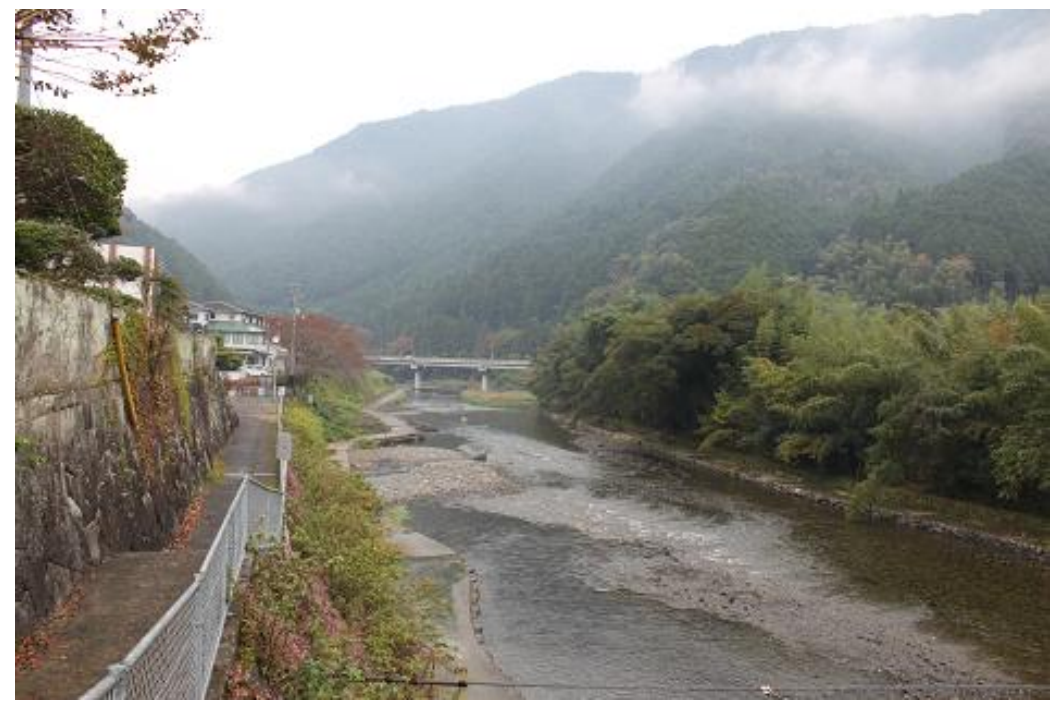

Figure 2. Nishiki River and the former Nishiki Town

Iwakuni City is an agglomeration of urban and rural bodies - and can be divided into a largely urban area along the coast and villages inland. The Yamashiro Area in the former Nishiki Town is a primarily rural landscape with a mountainous terrain. The area has the 


\section{I Macrothink}

Issues in Social Science ISSN 2329-521X 2014, Vol. 2, No. 1

highest average elevation among all urban and rural units in Yamaguchi Prefecture - narrow mountain valleys are carved out by rivers like Nishiki and Usa. The Jyakuchi River, an upland tributary of the Nishiki watershed, is registered as one of the 'beautiful waterways' in Japan by the Ministry of Environment (MoE) for its natural landscape (MoE, n.d.). In general, the area is known for its natural beauty, and idyllic villages (see Figure 2 above).

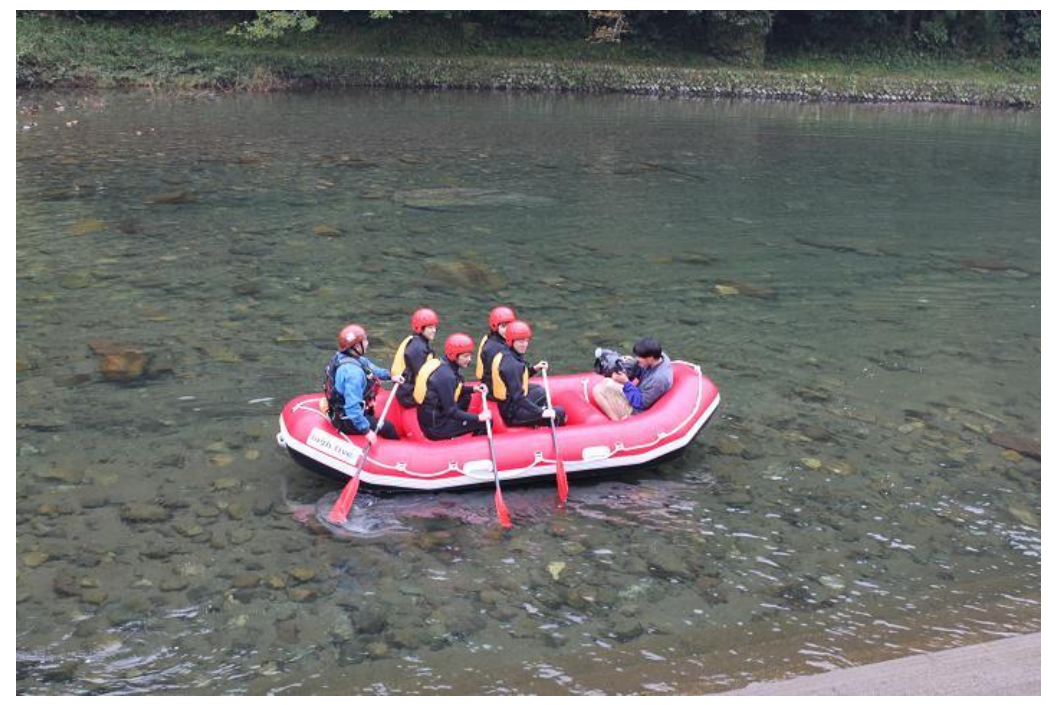

Figure 3. Filming a Promotion Video on the Nishiki River

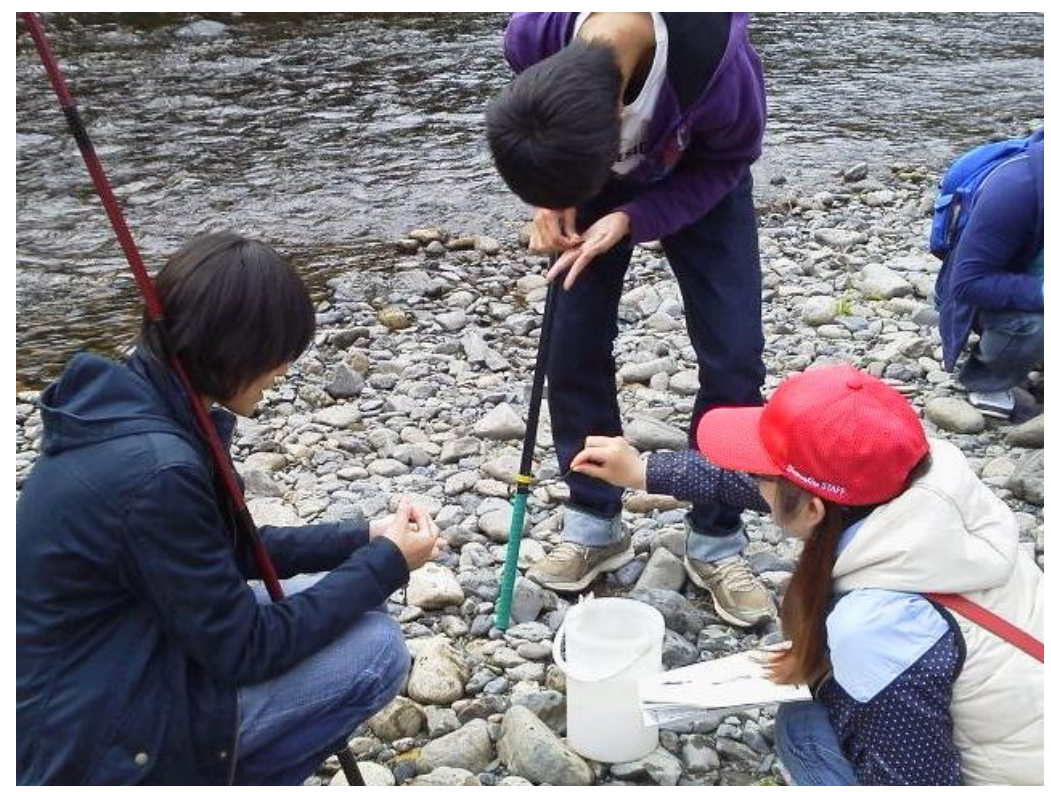

Figure 4. Students engage in fishing during a trip to the countryside

An NPO, 'Hotto Nishiki' was established in 2006 in this area to promote regional attractions. The NPO is engaged in promoting various types of tourism activities such as canoeing, fishing, cooking local delicacies and farming experiences (Figures 3 and 4 above). The formation of the NPO was directly related to the 2006 merger of urban and rural units, as local residents began to worry whether they would be sidelined from decision-making in the wake of centralization of administration in a distant location (Hotto Nishiki, n.d.). The idea 


\section{Macrothink Institute ${ }^{\mathrm{TM}}$}

was to provide a sense of reassurance to the local residents (the word Hotto in Japanese means 'relief') - and pursue a rural development program with local collaborators. The NPO website proclaims a unique brand of tourism for the area by focusing on the natural landscape of the Nishiki River basin. According to this approach, activities to engage in farming experiences (green tourism) and children's interactions with the river (river tourism or ecotourism) will be encouraged, successful examples will be studied and a main goal is to increase the number of repeat visitors. The vision statement is important because it mentions three points: that the natural landscape of the river basin is the most important tourism capital of the area, that schoolchildren will be a main focus of the activities, and that the organization will follow a path of trial and error, which can be seen as a form of adaptive tourism management with a community base.

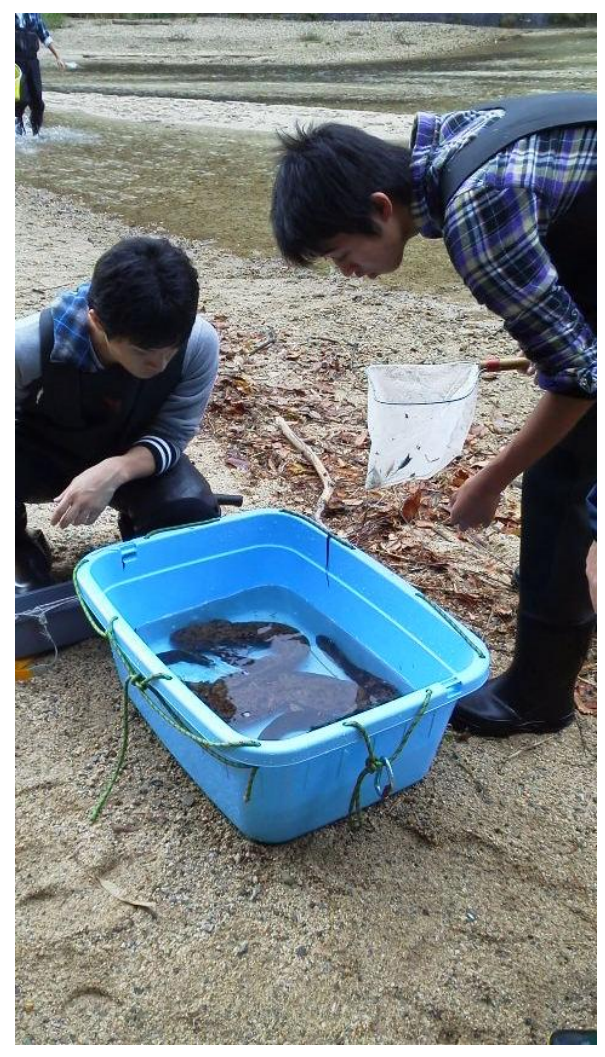

Figure 5. Students learning about protecting Japanese Salamanders

Beginning from 2011, a group of students from the Faculty of Economics at Yamaguchi University frequented the Yamashiro region for a year. In the initial phase, Hotto Nishiki played a crucial role by introducing local culture, lifestyle and rural tourism destinations to these students. Eventually, the students participated in a range of activities, such as trekking, riverside walking, filming trekking sessions, canoeing, rafting, preparing local cuisine, farming, learning about endangered species like the giant salamanders (Note 4) (see Figure 5 above) and escorting younger students from elementary to junior high school levels. These activities culminated in a seminar at Yamaguchi University and preparation of a report by student volunteers and researchers that was later presented to the local residents. 
Although the overall project was a success - it was warmly received by the local communities and fondly reflected upon by student participants - there were a few problems that hinted at why such activities have not succeeded uniformly at the national level. Firstly, the number of repeaters were less than half (9 out of 19) of the total number of students. This suggests that the majority of university students, who are otherwise busy with writing reports and searching for jobs, quickly switched their interest away from this rural area. Secondly, a key part of rural or green tourism is the length of the stay. Students were encouraged to visit the site multiple times to familiarize themselves with the seasonal changes in the land scape, but again, only a minority visited the site in different seasons. This indicates that even in those who were apparently interested to visit rural areas, a long term involvement with the place did not develop. While the short duration of the project (less than a year) may have been a contributing factor, it nevertheless suggests that the rural destinations did not interest a substantial part of students to the extent where they would repeat their trips.

\subsection{Shimane Prefecture: Reviewing a 'Model'of Integrating Rural and Urban Societies}

Shimane Prefecture, located next to Yamaguchi and to the Western seaboard of Japan, has the one of highest depopulation rates in Japan. In fact, it is the only prefecture where all comprising cities, towns and villages are either termed as 'depopulated areas' (kaso-chiiki), or are wholly or partially affected by shrinking population (Zenkoku Kaso Chiiki Jiritsu Sokushin Renmei, 2012). Shimane topped the prefecture level depopulation figures from 1955 to 2005: in half a century, the prefecture witnessed a net population decline of $20.1 \%$, while the fraction of people 65 and above also consistently ranked it as one of the most aged communities at the national level (Seki and Matsunaga, 2010). It is said that the Japanese word for depopulation. 'kaso' was first officially applied to describe a mass out-migration in the Hikimi Town area (now part of Masuda City), in the 1960s - and hence, Shimane is known as the point of origin of Japanese depopulation. Like Yamaguchi, Shimane is characterized by mountains and narrow valleys, making it one of the archetypal mountainous region landscapes in Japan. The depopulation rates are especially high in the Western part of the prefecture, in Hamada, Masuda Cities and Tsuwano and Yoshika Towns-which are part of an area referred to as the 'Iwami Region'.

The trigger to the depopulation in the prefecture is generally traced back to a particularly damaging snowstorm and series of avalanches that buried several mountain hamlets in the year 1963 (Seki and Matsunaga, 2010). 1963, 1964 and 1965 became three consecutive years of excessive snowfall, which crippled local industries and village life, forcing residents to leave the Hikimi region. 20 years later, in 1983, a flood devastated Masuda and Hamada areas, fragmenting yet more resident communities. Apart from such natural disasters, the general topography of the region precluded large industrial and urban development, and villagers consistently relocated themselves into nearby urban centers like Hiroshima and Okayama during the large part of the prefecture's postwar history.

As Shimane was the first prefecture to be seriously affected by rural depopulation, it became a frontrunner in devising responses to address rural decline (Seki, 2007). Seki has also proclaimed Shimane as a 'model' prefecture for the rest of Japan-he advocates the 'Shimane 
style' of revitalizing rural areas, by creating small scale 'local brands' and through 'link-up' of rural production and urban demand geographies. Seki and Matsunaga $(2009,2010)$ later developed this concept into a model of 'Agriculture, Industry (Note 5) and Business' (Nô-kô-shô renkei), or alternatively, a model of 'Lifestyle and Production.' A particularly interesting case is that of the Takatsu River Basin area-due to its 'naturally rich' landscape with unique local fishing and food-production traditions. We chose this area as our field study site in Shimane-our findings are discussed in the next sub-section of this article.

Shimane Prefecture, in general, has a variety of tourist attractions that are based on natural and cultural, landscapes. Notable examples are the Iwami Silver Mines (designated as UNESCO World Heritage Site in 2007), the Oki Islands Geopark that was designated as a Global Geopark in 2013, the historic town of Tsuwano (often locally referred to 'little Kyoto') and the Grand Shrine of Izumo. The Ama Island, located to the West of the mainland coast, has long stressed the idea of 'self-sufficiency' and 'local sustainability' — and has resisted amalgamation with the larger Matsue City (Meguri no Wa, 2012). The Ama Island has consistently emphasized the idea of 'exchange' (Community Travel Guide Henshû Iinkai, 2012), and actively sought to promote interactions with outsiders, especially by younger people and foreigners in the island, which is otherwise affected by the general trend of depopulation. In general, Shimane Prefecture witnessed a tourist growth of $9.3 \%$ between 2004 and 2009 (Seki and Matsunaga, 2010: 63).

In their work on the tourism in and around the Masuda City area (the Takatsu River Basin area), Seki and Matsunaga observe that in the general backdrop of visitor increase in the prefecture, Masuda City registered the most conspicuous figures, a rise of 39\% between 2004 and 2009. This rise is, however, not a reflection of a sudden cascade of green tourists, as figures during this period were boosted by the opening of the Grand Toit Art Museum in Masuda, which continues to be a major tourist attraction to this date. Seki and Matsunaga observe that 'slow' tourism (such as 'walking') is growing in the area, backed up by the popularity of Tsuwano Town, which they describe as a 'beautiful, historical land scape with colored fish swimming' in streams flowing through the townscape. Nevertheless, they note, Tsuwano was marketed as a tourist destination mainly by the mass media; certain parts of the landscape were chosen for this marketing and these areas did not necessarily reflect the ambition of the local residents. Another major success story, according to Seki and Matsunaga, is the concept of 'Michi no Eki' (Road stations) — spread across the Mito, Hikimi, Nichihara and Tsuwano areas. The Michi no Eki concept was developed by the MLIT in 1993: the idea was to provide selling space for local farmers and food producers in major highway junctions, and to develop these 'stations' as resting points where travelers could get acquainted with local culture and appreciate local hospitality. A typical Michi no Eki has well-managed toilets, food courts, souvenir shops, detailed maps of the area it is located in, and pamphlets featuring information on local customs, lifestyle and cultural events. These stations are observed to have had a significant impact in familiarizing rural products to urban visitors, thereby fostering urban-rural interaction at both national and local levels (Nakasawa, 2012). 
4.3 The Takatsu River Basin: Green Tourism and Civilian Engagement

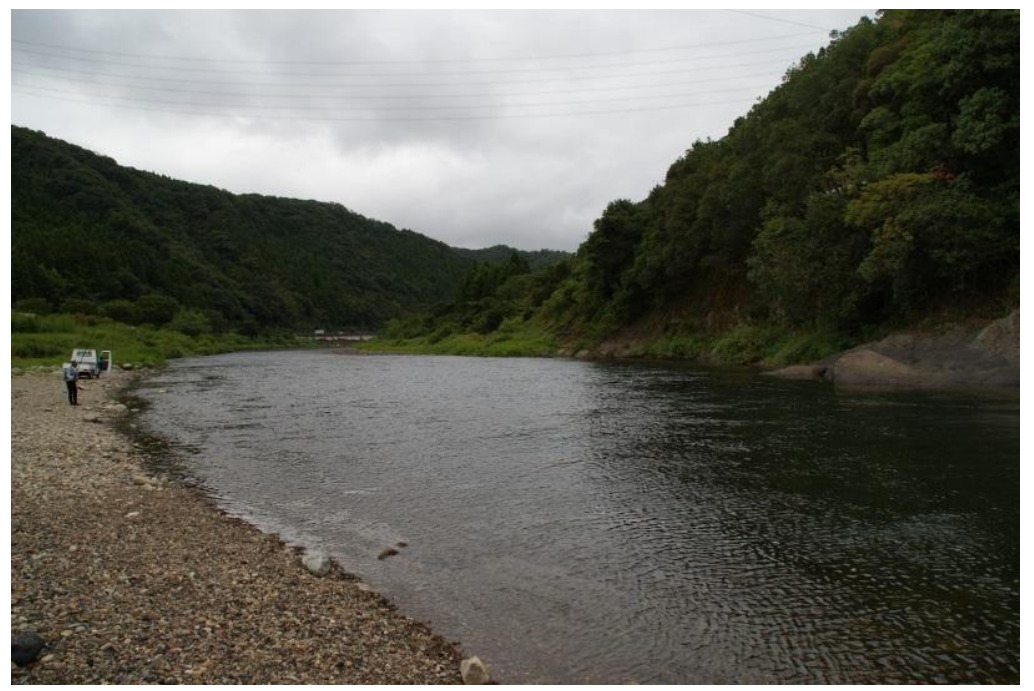

Figure 6. The Takatsu River flowing near Nichihara

One of the authors conducted research in the Takatsu River basin (photo in Figure 6 above) for a period spanning nearly three years: in this section, we mainly describe the findings of this ongoing research, particularly the aspects related to nature-based tourism.

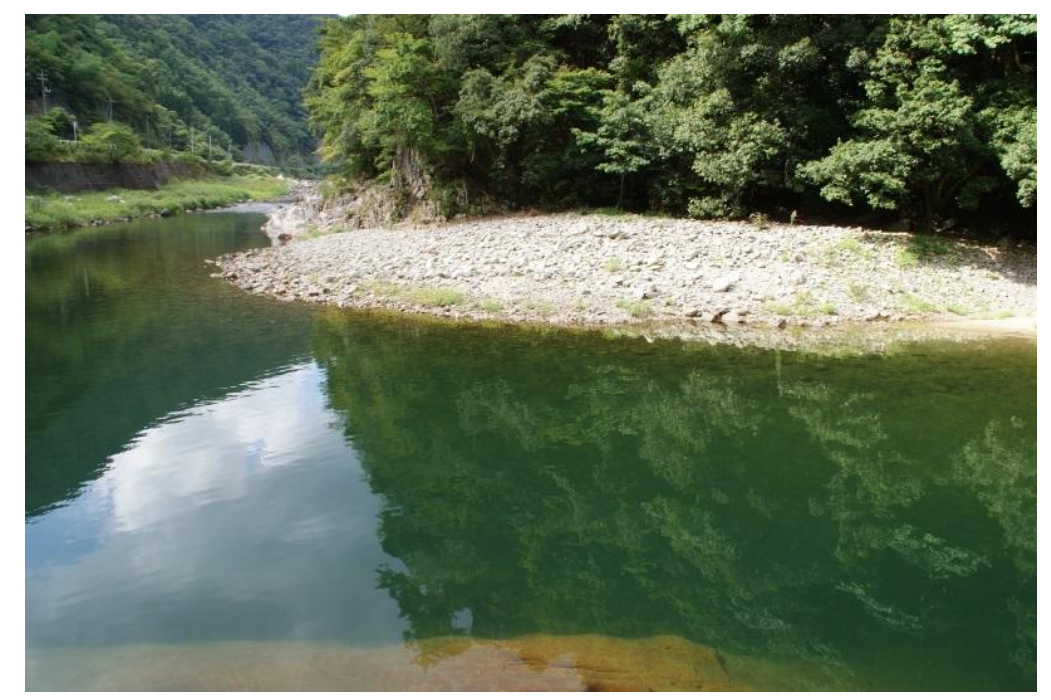

Figure 7. A pool in the Takatsu River, photo by the author. Recently such pools are undergoing rapid change, locals observe

The Takatsu River is an 81 kilometer long stream flowing from the Yoshika Town in West Shimane, to the Sea of Japan. The basin size is 1090 sq.km and the river is joined by several other streams on its way to the sea (MLIT, n.d.), such as the Hikimi River and the Tsuwano River. The river has topped national water quality surveys a number of times in the recent past, most recently in 2007-leading to the identity as the 'cleanest river in Japan' (Seiryû Nihon-ichi). The Takatsu is one of the very few rivers in Japan to flow without a large dam 


\section{MInstitute ${ }_{\text {Mnk }}^{\text {Macrothink }}$}

Issues in Social Science

ISSN 2329-521X

2014, Vol. 2, No. 1

(Shimane Prefecture, 2011) and it is also famous for its sweetfish (ayu) catch. The basin landscape is naturally diverse, with landforms like narrow gorges, large rocks standing on the waterway, meandering flow through mountain passes, distinct riffle and pool sequence (see Figure 7 above) and rich broadleaf forests in the upstream area (Shimane Prefecture, 2011). Local experts claim that as many as 80 fish species inhabit the river, apart from crustaceans and amphibians - making it one of the most dynamic river ecosystems left in a relatively natural condition in today's Japan (Toyota, 2012, personal correspondence).

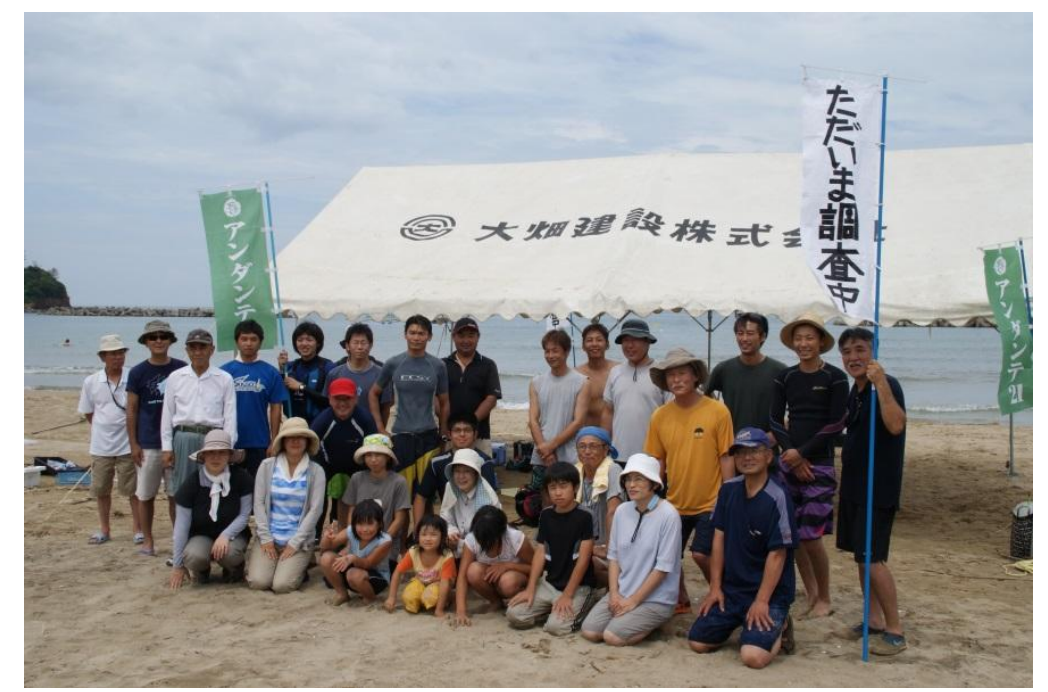

Figure 7. Andante 21 NPO workers with volunteering schoolchildren, after a 'survey' of the local Hamaguri clam population in Masuda City

However, the river remains underexplored as a destination for nature-based tourism. In addition, there is a lack of precise environmental data-no comprehensive source material is available in either print or digitized form (in Japanese) that studies the river and its rich ecosystem from an environmental point of view. A local NPO based in Masuda City, Andante 21 , is the most notable organization that seeks to address this knowledge vacuum: it is engaged in surveying the river landscape with layperson volunteers and its own small group of specialists (one of the field study sessions carried out by the NPO is photographed in Figure 8 above). Andante 21 has had some amount of success in evaluating the natural ecosystems and potential of nature-based tourism in the basin area: its surveys on the rare Hamaguri clams found in the rivermouth area suggest that there is a strong correlation between flow dynamics, upland forest conversion and the population of the clams. The NPO has been successful in partially preserving a critically endangered species of waterborne flowering plant, the Himebaikamo (Ranunculus kadzusensis Makino) in the watershed. Andante 21 has also recently started an effort to develop a 'theme park' and a 'nature trail' along the river, and it hopes to eventually designate the area as a hub of nature based tourism (Toyota, 2012, personal correspondence).

Although the Takatsu River is one of the most dynamic rivers left in Japan, it still faces a number of critical issues. Our research results suggest that the river has witnessed a drastic reduction in the flow volume in the recent past, which is possibly correlated with upland 
forest conversion (change of broadleaf forest cover to coniferous plantations leading to a deterioration of water-retention function of the upstream forests), there are more than one location where significant eutrophication can be observed (partially related to the lack of the flow volume), and that the physical properties of the pools in the riffle and pool sequences have changed towards higher levels of thermal pollution (consistent with a shallower river). In the postwar period, most Japanese rivers were subjected to extensive engineering projects and lost their natural riffle and pool sequences (Chakraborty, 2012), which are a key to a river's natural fish stock. Although the Takatsu remains a popular sweetfish fishing ground, inter-species variety has declined steadily. In addition, some of the tributary rivers like the Tsuwano River carry a significantly high pollutant load - which adds to the deterioration of the natural environment.

A particularly interesting aspect of tourism in the basin is the involvement of the local civil society. As observed above, Andante 21 is monitoring the basin environment, and exploring the potential of nature-based tourism. Nearly all participants who sustain these efforts are volunteers. Andante 21 aims to expand the scope of nature based tourism by attracting local administrative authorities, and since 2013 it has joined hands with the Shimane Prefecture Office to develop a nature trail. It is also developing a digital database of natural resources, tourist spots and important cultural landscapes in the basin through Geographical Information Science (GIS) - this project is also supported by prefectural aid. Most volunteer participants who are associated with nature conservation or tourism promotion have a background of engaging with the river: either as professional fishermen, or forestry workers, or farmers. The region has also seen an expansion of organic farming: with local products such as the Nameko mushroom (Hikimi area) as flagship brands, apart from the usual emphasis on producing good quality rice.

\section{Discussion: 'Green Tourism': Key for Revitalizing the Region?}

From the foregoing description of green tourism and regional revitalization efforts in the two cases of Yamaguchi and Shimane Prefectures, several points can be noted. We see these as typical features of mountainous regions in Japan-particularly for those areas which face problems like aging society and depopulation, and are considered 'remote' due to their distance from large urban centers and 'backward' due to the lack of large industrial complexes.

Firstly, it can be claimed that green tourism in mountainous regions of Japan is driven more by the 'rural revitalization' agenda and less by the nature conservation agenda. This is seen in both the cases of Yamashiro and Takatsu River basin areas, where the typical focus is on 'revitalizing' declining communities. In this sense, green tourism is based on the idea of 'repackaging' the rural destination and aimed at increasing tourist numbers. Particularly in the case of the Takatsu River basin, our research suggests that the quality of the natural environment has actually declined over the years, though there was some degree of success in restoring a few key species due to active civilian monitoring of the basin ecosystems. A number of local respondents suggested that the extensive redesigning of the Tsuwano River, with the primary goal of decorating the landscape of the Tsuwano town, affected its riparian 
environments adversely. Comprehensive environmental impact reports are non-existent, and existing research articles such as Seki and Matsunaga (2010) look mainly at the 'economic' part of revitalization initiatives: the researchers describe the 'historical town-scape' of Tsuwano in positive terms, and do not analyze ecological implications of revitalization or tourism development schemes.

Secondly, the cases indicate that with demographic change in Japan, tourism patterns are changing. This finding supports the argument of Jones (2012) regarding the general transition in Japanese tourism. Our findings also indicate that revitalizing declining areas through green tourism is an emerging policy objective mainly due to the strong attachment of the Japanese society to rice-farming. In both of our cases, nature-based or 'green' tourism arose out of efforts to conserve the 'furusato' (Note 6) village landscape, the origin of the NPO Hotto Nishiki is a case in point in this regard. Green tourism, as exemplified by the Hotto Nishiki case, has also evolved as a means to attract funding and attention for rural societies which fear further sidelining due to merger of rural units into large municipal bodies.

Thirdly, it can be observed that despite the primary focus on regional revitalization goals and persisting problems with the environment, rural 'green' tourism has actually resulted in a reevaluation of the rural landscape. While the term 'rural' is created and handled as a form of tourism capital, the root that sustains this capital is the natural landscape. This realization has helped set the landscape conservation agendas at the local level. Typically, both cases feature an emphasis on 'experiencing nature' - based on slow, direct and on-the-spot (chakuchigata) forms of tourism, which are very much opposite to the urban-centered, high-speed mass tourism methods. Thus, it can be observed that though the primary agenda is revitalizing rural communities, the natural capital of the landscape is vital for sustaining these communities.

Fourthly, a conspicuous trend is the involvement of school students, university students, and the civil society in green tourism activities. In the case of Yamashiro, Yamaguchi University students developed a good relationship with the local communities. Yamaguchi prefecture in general has enjoyed a remarkable growth as a rural tourism destination, this almost certainly bodes well for the consolidation of nature-based tourism in the area. This type of activity is encouraged by both prefecture level and national level authorities, and possibly indicates a trend where tourism planners are becoming increasingly aware of the prospects of developing green tourism in Japan's depopulated countryside.

Fifthly, both cases help shed light on some important challenges. University level student involvement remains sporadic, and the rural areas are rarely perceived as 'places to live in' by urban residents. This negative perception hinders the scope of participatory tourism management. It is also intriguing that while planners emphasize urban-rural exchange, there is no comparable initiative to link up similarly affected rural areas.

Finally as a sixth and separate point, it is worth reemphasizing that the deterioration of the natural environment and the lack of reliable monitoring form the most important set of challenges for developing sustainable green tourism. As the Takatsu River case shows, many rural areas in Japan must add ress both issues of regional revitalization and conservation of the natural landscape at the same time. This will require more financial commitment from the 
authorities and systematization of participatory environmental monitoring. In short, more efforts are needed to evaluate the condition of the natural environment, which provides the base for this type of tourism.

\section{Conclusion}

In this paper, we discussed two cases of green tourism in Japan's mountainous regions. We described the general condition of these regions, which are witnessing a demographic transition towards shrinking communities, loss of farming hands, and peripherality. We then observed the unique features of green tourism in these regions, and concluded that green touris $m$ here has evolved as a vehicle for regional revitalization, but it also aids a re-evaluation the human relationship with nature. We also identified some important challenges - such as the low level of participation by urban stakeholders, absence of environmental monitoring, and deterioration of the natural landscape in some cases - as well as gaps between ideals and practice, mainly exemplified through the point that the nature conservation agenda has lagged behind the economic revitalization agenda. An important finding of this study is that rivers are an emerging focus of green tourism and regional revitalization in Japan. Both study areas derive a major part of their identity from rivers (Nishiki River for Yamaguchi and Takatsu River for Shimane) and ongoing green tourism activities in both areas converge on the common theme of beautiful river basin landscapes sustaining farming villages.

It is finally worth asking, what are the lessons these cases offer for nature based tourism in general, and what can be the implications at a wider, possibly global level? The answer to these questions is a twofold one.

In the case of Japan, 'green' tourism is actually a standardized term used to describe a range of tourism activities conducted in rural areas, or semi-natural land scapes. A main feature of this type of tourism is said to be the interaction between urban and rural communities. When we consider that Japan is a society with strong day to day and symbolical attachment to rice farming, this becomes an interaction between food producers and consumers. This kind of rural tourism, based on food systems, has also gained popularity in Europe (Sidali et al. 2011, Campbell and Lopez-Ortiz, 2011). Furthermore, as Japan is poised to become the country with the most rapid population shrinkage experienced among industrialized nations by the middle of this century (The Japan Times, 2013) — the findings on how rural tourism has become a regional revitalization pathway and the prospects and challenges of rural touris $m$ have significant implications for nature-based, sustainable tourism in general. A particularly important lesson is that while ministerial organs like the MAFF have been prominent in the standardization of the rural tourism discourse in Japan, important regional variants exist, and continue to develop as distinct forms of tourism based on local perceptions of nature. Secondly, a key feature of Japanese green tourism is the engagement of the civil society. In this study, we focused on the activities of two NPOs in Yamaguchi and Shimane. In general NPO involvement in Japan's rural tourism is on the rise, making it one of the most dynamic fields to study the impact of tourism at the local level. In addition, involvement of schoolchildren and university students is another emerging pathway for the diffusion of 
nature-based tourism activities. Both types of interactions are dependent on the rural communities, especially on the older generation who provide relevant knowledge of the landscape, ecosystems, and keep track of long term changes. It is in this sense that the rapidly aging but still active societies of Japan's mountainous regions offer a vital resource for sustainable, nature based tourism.

\section{References}

Ackerman, P., Martinez, D., \& Del Alisal, M. R. (2008). Pilgrimages and spiritual quests in Japan. London: Routledge.

Aoki, S. (2010). Tenkan suru green tsûrizumu: Kôiki renkei to jiritsu wo mezashite (The changing cace of green tourism: Interregional link-up and autonomy related issues). Kyoto: Gakugei Shuppansha.

Asamizu, M. (2012). Rural tourism as a means to mitigate rural disparity in Japan. In A. Kagermeier \& J. Saarinen (Eds.). Transforming and managing destinations: Tourism and leisure in a time of global change and risks (pp. 237-242). Manheim Conference Proceedings.

Campbell, W. B., \& Lopez Ortiz, S. (Eds). (2011). Integrating agriculture, conservation and ecotourism: Examples from the field. New York: Springer. http://dx.doi.org/10.1007/978-94-007-1309-3

Chakraborty, A. (2012). Promises unfulfilled: Ta shizengata kawazukuri and environment oriented river basin governance in Japan. Asia Pacific world, 3(2), 83-107. http://dx.doi.org/10.3167/apw.2012030207

Chûsankan Chiiki wo Kangaeru Kai. (N.D.). Nihongata gurîn tsûrizumu wo kangaeru (On Japanese green tourism). Accessed from http $/ / \mathrm{www} . j \mathrm{ichiro.gr.jp/jichiken \_ kako/report}$ /rep_tokushima29/jichiken/3/3_2_16.htm

Community Travel Guide Henshû Iinkai. (2012). Amajin: Oki no shima, Amachô hitobito ni deau tabi (The Ama people: Meeting local communities in Oki islands and Amacho area). Tokyo: Eiji Shuppan.

Creswell, J. W. (2002). Research Design: Qualitative, quantitative and mixed method approaches. Thousand Oaks: Sage.

Faruqee, H., \& Muhleisen, M. (2001). Population aging in Japan: Demographic shock and fiscal sustainability. IMF working paper WP/01/40. Accessed from http://lnweb90. worldbank.org/Caw/CawDocLib.nsf/0/C7C1676DEBF94B8085256C72007A A0E1/\$file/wp0140.pdf

Francis, C., Moncure, S., Jordan, N., Breland, T. A., Lieblein, G. Salomonsson, L., Wiedenhoeft, M., Morse S., Porter, P., King, J., Perillo, C. A., \& Moulton, M. (2012). Future visions for experimental education in the agroecology learning landscape. In W. B. Campbell, \& S. Lopez Ortiz (Eds), Integrating agriculture, conservation and ecotourism: Societal influences. New York: Springer. http//dx.doi.org/10.1007/978-94-007-4485-1_1 
Hotto Nishiki. (n. d.). Accessed from http://www.hotnishiki.jp/info.html

Inoue, K., Nakamura, K., \& Yamazaki, M. (1996). Nihongata gurîn tsûrizumu (Japanese green tourism). Matsudo: Toshi Bunkasha.

JSSA. (2010). Satoyama Satoumi Ecosystems and human well being: Socio-ecological production landscapes of Japan. Tokyo: United Nations University.

Kawagoe, T. (1999). Agricultural land reform in postwar Japan: Experiences and issues. World Bank policy research working paper 2111. Accessed from http://213.154.74.164/invenio/record/12017/files/kawagoe.pdf

MAFF, (n. d.). Gurîn tsûrizumu toshi to nôsan gyôson no kyôsei-tairyû (Green tourism based on exchange between cities and mountain and fishing villages). Accessed from http://www.maff.go.jp/j/nousin/kouryu/kyose_tairyu/

MAFF. (n. d.). Chûsankan chiiki to wa (Mountainous regions of Japan: An introduction). Accessed from http://www.maff.go.jp/j/nousin/tyusan/siharai_seido/s_about/cyusan/

Matanle P., \& Rausch A. (with the Shrinking Regions Research Group). (2011). Japan's shrinking regions in the $21^{\text {st }}$ century. New York: Cambria Press.

Meguri no, W. (2012). Bokutachi wa shima de mirai wo miru kotoni shita (We Decided to Build our Future in an Island). Tokyo: Sotokoto.

Miyashita, S. (2006). Nihongata gurîn tsûrizumu no tokushitsu to chiikiteki tenkai: Nagano ken Shiga mura wo jirei to shite (Characteristic and local process of Japanese style green tourism: A case study of Shiga-mura in Nagano). Ritsumeikan sangyô Shakai ronshû (Industrial sociological research papers of Ritsumeikan University), 42(3), 109-131.

Miyazaki, T. (2000). Kankyô hozen to kôryû no chiikizukuri: Chûsankan chiiki no shizen shigen kanri sisutemu (Conservation based revitalization of rural areas: Natural resource management in the mountainous regions of Japan). Tokyo: Showado.

Miyazaki, T. (2011). Nôson komiunitî bijinesu to gurîn tsûrizumu: Nihon to Ajia no murazukuri to suiden nôhô (Agricultural community business and green tourism: Rural revitalization and rice paddy reform law in Japan and Asia. Tokyo: Nôrin Tôkei Kyôkai.

MLIT. (n. d.). Takatsugawa: Yutakana shizen to seiryû wo ikasu kawazukuri (Takatsu river: Constructing rivers with beautiful nature and clean water). Accessed from http://www.cgr.mlit.go.jp/cginfo/syokai/busyo/kasen/suikei/takatu.htm

MOE. (n. d.). Meisui hyakusen Jyakuchigawa (100 scenic waterways of Japan: Jyakuchi river). Accessed from https://www2.env.go.jp/water-pub/mizu-site/meisui/data /index.asp? info=73

Nakasawa, S. (2012). Michi no eki Hagi shi-ma-to ga hansei shite iru wake (Reasons behind the success of Hagi sea mart road station). Tokyo: Godo Shuppan.

Ogawa, N., \& Retherford, R. D. (1993). The resumption of fertility decline in Japan: 
1973-1992. Population and development review, 19(4). http//dx.doi.org/10.2307/2938411

Ohnuki-Tierney, E. (1993). Rice as self. New Jersey: Princeton University Press.

Ono, A. (2008). Genkai shûraku to chiiki saisei (Regional resuscitation with extremely depopulated villages). Kyoto: Kyoto Shimbun Kikaku Jigyô

Patton, M. Q. (2001). Qualitative research \& evaluation methods. Thousand Oaks: Sage.

Retherford, R., D. Ogawa, N., \& Sakamoto Satomi. (1996). Values and fertility change in Japan. Population studies, 50, 5-25. http://dx.doi.org/10.1080/0032472031000149016

Richards, G., \& Munsters, W. (2010). Cultural tourism research methods. Wallingford: CABI. http://dx.doi.org/10.1079/9781845935184.0000

Seki, M. (2007). Chihô ken no sangyô shinkô to chûsankan chiiki: Kibô no Shimane moderu sôgô kenkyû (Regional production promotion and mountainous regions of Japan: Shimane case as a 'model of hope'. Tokyo: Shinhyôron.

Seki, M., \& Matsunaga, K. (2009). Chûsankan chiiki no jiritsu to nô-shô-kô renkei: Shimane ken chûsankan chiiki no Genjô to kadai (Agriculture, production and business link up for self-sustenance of mountainous regions: Issues and scenario of the mountainous region of Shimane prefecture). Tokyo: Shinhyôron.

Seki, M., \& Matsunaga, K. (2010). Nô to monozukuri no chûsankan chiiki (Agriculture and production in the mountainous regions of Japan). Tokyo: Shinhyôron.

Shimane Prefecture. (2011). Kanoashi no fûkei: Seirŷ̂u Takatsu gawa (Natural scenery of Kanoashi area: Takatsu river). Accessed from http://www.pref.shimane.lg.jp/masuda_kendo/tsuwano_doboku/kanoashi_huukei_takatsu_ga wa.html.r

Sidali, K. L., Spiller, A., \& Schulze, B. (2011). Food, agriculture and tourism: Linking local gastronomy and rural tourism: Interdisciplinary perspectives. New York: Springer.

Takata, I. (2013). Gurîn raifu tsûrizumu no sôzô: Niu tsûrizumu to chakuchigata tsûrizumu (Designing green life tourism: New tourism and 'on the spot' tourism). Tokyo: Fuyoshobo Shuppan.

The Japan Times. (2013). Japan's depopulation time bomb. April 17. Accessed from http://www.japantimes.co.jp/opinion/2013/04/17/editorials/japans-depopulation-time-bomb

Vaccaro, I., Smith, E. A., \& Aswani, S. (2010). Environmental social sciences: Methods and research design. Cambridge: Cambridge University Press. http://dx.doi.org/10.1017 /CBO9780511760242

Van de Kaa, D. (1997). Europe's second demographic transition. Population bulletin, 42, 3-57.

Yamaguchi Prefecture, (2013). Jinkô idô tôkei chôsa (Statistical report of population trends). Accessed from http://www.pref.yamaguchi.lg.jp/cms/a12500/jinko/jinko.html 


\section{Macrothink

Yamaguchi Prefecture. (2013). Yamaguchi ken jûyô kiso dêta (Vital statistics of Yamaguchi). Accessed from http://www.pref.yamaguchi.lg.jp/cms/a13200/kiso-data/data.html

Yamauchi, K., \& Shiraishi, K. (2010). Chûgoku sanchi seibu Nishikigawa suikei, Usagawa ni okeru kasen sôdatsu (River divisions in the mountainous regions of Chugoku region, N ishiki and Usa river valleys). Ritsumeikan Chirigaku (Ritsumeikan University Geography Bulletin), 22, 39-57. Accessed from http://www.ritsumei.ac.jp/acd/cg/lt/asp/research/geo/journal/ pdf.geo-journa1/22-2010-yamauchi.pdf

Zenkoku Kaso Chiiki Jiritsu Sokushin Renmei. (2012). Kaso chiiki no dêtabanku (Databank of depopulated regions). Accessed from http://www.kaso-net.or.jp/kaso-db.htm

\section{Notes}

Note 1. Satoyama is the Japanese term for a broad range of managed landscapes, usually created out of the interaction between sedentary societies and nature. The term is defined as: "... a mosaic of different ecosystem types - secondary forests, farm lands, irrigation ponds, and grasslands - along with human settlements, which has been managed to produce bundles of ecosystem services for human well-being" (JSSA, 2010: 4).

Note 2. Nôson Kyûka Hô. This law is also called Green Tourism Hô in Japanese.

Note 3. Towa Town is now Suo-Ôshima city, Aga and Nishiki Towns are parts of Iwakuni City, Kumage Town is in Shunan City and Ato has become a part of Yamaguchi City.

Note 4. The Japanese giant salamander, ôsanshouo-is one of the largest amphibian species in the world. The species used to be widespread in Japanese rivers, but their numbers have dwindled recently.

Note 5. Seki and Matsunaga generally imply small scale industries like food production, processing and apparel often based on household basis - through the term 'industry'. 